\title{
Tanggung Jawab Hukum Badan Pertanahan Nasional Terkait Ketidaksesuaian Hasil Pengecekan Sertifikat Secara Elektronik
}

\author{
Ni Made Rian Ayu Sumardani', I Nyoman Bagiastra ${ }^{2}$
}

${ }^{1}$ Kantor Notaris I Nyoman Mustika, S.H., M.Hum, E-mail: rianayu_sumardani@yahoo.com 2Fakultas Hukum Universitas Udayana, E-mail: nyoman_bagiastra@unud.ac.id

\begin{tabular}{l}
\hline Info Artikel \\
\hline Masuk : 4 Maret 2021 \\
Diterima :22 Juni 2021 \\
Terbit : 1 Juli2021 \\
Keywords: \\
Legal Responsibility; Electronic \\
Certificate Checking; \\
Indonesian National Land \\
Office; \\
\\
\\
\\
Kata kunci: \\
Tanggung Jawab; Pengecekan \\
SertifikatElektronik; Badan \\
Pertanahan Nasional
\end{tabular}

\begin{abstract}
The aim of this paper are to discover the regulation of electronically checked documents and to examine the legal responsibility of the Indonesian National Land Office based on the Regulation the Minister of Agrarian 5/2017. The research method applies a normative legal research. Results indicated that electronically checked documents, which examine based on the regulation stated in Article 1 paragraph 2 letter a of the Regulation the Minister of Agrarian 5/2017 which is where electronic certificate checking will replace manual certificate checking as regulated in the Regulation of the Head of the National Land Agency 8/ 2012. Legal responsibility related abouterrors in the results of checking certificates electronically is the responsibility of BPN in accordance with Article 10 paragraph (4) and paragraph (5) of the Regulation the Minister of Agrarian 5/2017 with legal responsibility in the form of clarification explanation and improvement of the database system.
\end{abstract}

\section{Abstrak \\ Tulisan ini memiliki tujuan untuk mengetahui pengaturan pengecekan sertifikatsecara elektronik dan mengkaji tanggung jawab Badan Pertanahan Nasional terkait ketidaksesuaian hasil pengecekan sertifikatdalam Permen Agraria5/2017. Penelitian ini menggunakan metode penelitian hukum normatif. Hasil penelitian menunjukkan bahwa, pengaturan pengecekan sertifikat secara elektronik diatur pada pasal 2 ayat (2) huruf a Permen Agraria 5/2017, yang dimana pengecekan sertifikat secara elektronik akan menggantikan pengecekan sertifikat secara manual yang diatur pada Perkaban No. 8/2012. Tanggung jawab hukum terkait adanya kesalahan pada hasil pengecekan sertifikat secara elektronik merupakan tanggung jawab dari pihak BPN sesuai dengan Pasal 10 ayat (4) dan ayat (5) Permen Agraria 5/2017 dengan tanggung jawab hukum berupa klarifikasipenjelasan dan perbaikan pada sistem pangkalan data.}




\section{Pendahuluan}

Pemberian kepastian hukum atas hak-hak pemilik tanah menjadi hal yang sangat penting. Kepastian hukum kepemilikan tanah diawali dengan produk hukum berupa sertifikat kepemilikan tanah yang diterbitkan oleh Badan Pertanahan Nasional (selanjutnya disebut BPN). Pendaftaran tanah dilakukan untuk melindungi hak-hak masyarakat terhadap kepemilikan tanahnya. ${ }^{1}$ Adanya pemberian kepastian kepada masyarakat dari objek dan subjek hak tentunya diperlukan dalam penegakan hukum terkait hak-hak atas tanah, sehingga untuk menjamin pemberian kepastian hukum tersebut beberapa negara menyelenggarakan sistem keterbukaan, yang artinya dengan sistem keterbukaan setiap orang dengan mudah dapat mengetahui kepemilikan dari segala hak atas tanahnya dan perbuatan hukum apa saja yang telah terjadi mengenai tanahnya. ${ }^{2}$ Pemberian informasi mengenai hak atas tanah serta perbuatan hukum mengenai tanahnya maka BPN melakukan peningkatan pelayanan jasa, dimana dalam hal ini BPN adalah lembaga pemerintah nonpemerintah yang tanggung jawabnya di bidang pertanahan sebagai satuan kerja.

Peningkatan pelayanan jasa ini, tidak lepas dari adanya informasi elektronik. Informasi dalam bentuk apapun baik itu tertulis yang identik dengan sebuah informasi atau dokumen dapat diberikan melalui media elektronik. Dalam lingkup informasi elektronik, informasi yang asli dengan salinannya tidak memiliki perbedaan dikarenakan informasi yang didapatkan berupa elektronik merupakan suatu penggandaan informasi yang dapat dipahami oleh beberapa orang tertentu yang mampu memahaminya. Peningkatan ini pula tidak lepas dari tuntutan pemanfaat teknologi yang berkembang seperti halnya cyber notary. ${ }^{3}$

Pada proses pengecekan sertifikat, BPN melakukan proses pengecekan data fisik yang berupa pengecekan letak situasi tanah yang tercantum dalam sertifikat hak atas tanah dengan metode pengecekan secara langsung ke lapangan, sedangkan pada pengecekan data yuridis, pengecekan dilakukan dengan menyesuaikan data-data yang termuat pada sertifikat buku tanah yang ada di kantor BPN.

Perubahan sistem pelayanan yang dulunya bersifat manual kemudian berubah menjadi elektronik telah terjadi di BPN dengan terbitnya Peraturan Menteri Agraria dan Tata Ruang/ Kepala BPN Republik Indonesia Nomor 5 Tahun 2017 Tentang Layanan Informasi Pertanahan Secara Elektronik (selanjutnya disebut Permen Agraria 5/2017). Untuk mendapatkan informasi elektronik terkait tanah dapat dilakukan dengan Pengecekan Sertifikat pada Layanan Aplikasi Pengecekan Tanah yang telah diatur pada pasal 1 angka 5 yang mengatur bahwa, Layanan Pengecekan Tanah adalah sebuah layanan yang dipergunakan untuk melakukan pemeriksaan dan menyesuaikan

\footnotetext{
1 Putri, C. A., dan Gunarto, G. (2018). Efektivitas Pengecekan Sertifikat Terhadap Pencegahan Sengketa Tanah Dalam Proses Peralihan Hak Atas Tanah. Jurnal Akta,5(1), h. 268, doi http://dx.doi.org/10.30659/akta.v5i1.2611.

2 Arba, H.M. (2018). Hukum Agraria Indonesia. Jakarta: Sinar Grafika, p.15

3 Widiasih, N.K. A. E. A Kewenangan Notaris dalam Mensertifikasi Transaksi vang Dilakukan Secara Elektronik (Cyber Notary). Acta Comitas: Jurnal Hukum Kenotariatan, 5(1), h. 151, doi https://doi.org/10.24843/AC.2020.v05.i01.p13.
} 
data fisik dan data yuridis yang terdapat pada sertifikat hak atas tanah pada data elektronik yang tersimpan melalui pangkalan data BPN.

Pengecekan Sertifikat tanah wajib dilakukan oleh Pejabat Pembuat Akta Tanah (selanjutnya disebut PPAT), hal ini berfungsi untuk memberikan kepastian bahwa sertifikat tersebut bebas dari keadaan sengketa, tidak sedang dalam jaminan atau tidak sedang dalam keadaan penyitaan atau sita jaminan atau telah terjadi perubahan data yang bersangkutan, sehingga PPAT dapat menentukan tindakan yang akan dilakukan untuk melanjutkan proses perbuatan hukum pada sertifikat hak atas tanah tersebut. 4 Berdasarkan Permen Agraria 5/2017 pada pasal 4 yang menegaskan bahwa PPAT diwajibkan melakukan pengecekan sertifikat hak atas tanah sebelum membuat suatu akta perbuatan hukum yang nantinya akan mengalihkan hak dari tanah tersebut.

Mengenai hasil dari pengecekan secara elektronik masuk dalam kategori Dokumen Elektronik yang diatur berdasarkan Pasal 1 angka 2 Permen Agraria 5/2017 adalah, dokumen elektronik yang berisikan informasi bentuk digital atau elektronik sehingga dapat ditampilkan melalui komputer atau sistem elektronik, termasuk didalamnya berupa tulisan, gambar, suara ata sejenisnya dan hanya dapat dipahami oleh orangorang tertentu yang mampu memahaminya.

Kemudahan untuk pengecekan sertifikat hak atas tanah secara elektronik sangat meringankan pekerjaan PPAT. Namun pada perjalanan pengecekan sertifikat hak atas tanah yang dilakukan secara elektronik, terdapat ketidaksesuaian pada hasil pengecekan tersebut. Ketidaksesuaian dari pengecekan sertifikat hak atas tanah secara elektronik seperti berupa perbedaan nama pemilik sertifikat hak atas tanah, tanggal lahir pemilik, ataupun ketidaksesuaian perbuatan hukum yang tercantum didalam sertifikat hak atas tanah.

Ketidaksesuaian ini mengurangi kepercayaan PPAT yang dalam hal ini merupakan kuasa dari pemilik sertifikat hak atas tanah kepada BPN terkait pemberian kepastian hukum data yang tersimpan dalam pangkalan data BPN. Hal ini dikarenakan BPN sebagai penyelenggara pendaftaran tanah wajib menerapkan asas-asas yang terdapat pada pendaftaran tanah yang diatur dalam Peraturan Pemerintah Nomor 24 tahun 1997 tentang Pendaftaran Tanah (selanjutnya disebut PP 24/1997) sebagai peraturan penyelenggaraan pendaftaran tanah. ${ }^{5}$ Ketidaksesuaian ini diperlukan tanggung jawab dari pihak BPN dikarenakan dokumen elektronik tersebut diterbitkan oleh BPN berdasarkan pasal 10 ayat (4) Permen Agraria 5/2017 yang mengatur bahwa BPN memiliki tanggung jawab atas segala informasi yang tercantum ataupun tertulis pada hasil pengecekan sertifikat secara elektronik.

Ketidaksesuaian pada hasil pengecekan sertifikat juga akan menimbulkan kerugian pada masyarakat yang menanyakan mengenai kekuatan hukum dari pengecekan sertifikat secara elektronik yang berbeda hasilnya dengan sertifikat aslinya. Padahal

\footnotetext{
${ }^{4}$ Setiawan, D. A. (2018). KeabsahanSurat Kuasa Membebankan Hak Tanggungan dalam Proses Peralihan Kredit Antar Bank. Jurnal Hukum dan Kenotariatan, 2(2), e-ISSN: 2655-7789, h. 171, http://riset.unisma.ac.id/index.php/hukeno/article/download/1500/1473.

${ }_{5}^{5}$ Yamin, M., dan Zaidar, Z. (2018). Pendaftaran Tanah dalam Mewujudkan Kepastian Hukum atas Kepemilikan Tanah dan Upaya Meminimalisir Konflik Pertanahan. Jurnal Hukum Samudra Keadilan, 13(2), h. 203, doi https:// doi.org/10.33059/jhsk.v13i2.911.
} 
masyarakat melakukan pengecekan sertifikat dengan tujuan mendapatkan kepastian hukum, akan tetapi masyarakat harus menempuh jalur hukum dikarenakan tidak mendapatkan kepastian dari pihak BPN. Kerugian yang timbul pada ketidaksesuaian hasil pengecekan sertifikat juga terdapat pada terhambatnya proses jual-beli antara penjual yang membutuhkan dana cepat, terkendala pada hasil pengecekan sertifikat yang tidak sesuai akibat dari kesalahan BPN yang tidak memperbaharui sistem pangkalan datanya.

Penjelasan bentuk tanggung jawab tidak dijelaskan pada Permen Agraria 5/2017, sehingga akan menimbulkan penyalahgunaan wewenang oleh BPN dalam memberikan pertanggung jawaban kepada PPAT yang telah membayar Penerimaan Negara Bukan Pajak (selanjutnya disebut PNBP). Hal ini dikarenakan dokumen elektronik tersebut tidak dapat digunakan sebagai acuan PPAT yang merupakan kuasa dari pemohon untuk melanjutkan proses perbuatan hukum. Sehingga secara tidak langsung PPAT yang telah membayar PNBP pengecekan secara elektronik mengalami kerugian, karena hasil yang didapatkan dari BPN berupa dokumen elektronik yang salah. PPAT mengulang melakukan pengecekan sertifikat hak atas tanah untuk mendapatkan dokumen elektronik yang sudah diperbaiki. Padahal semestinya apapun yang terdapat dalam pangkalan data BPN harus disesuaikan dan diperbaharui dengan keadaan di lapangan sesuai dengan penerapan dari Asas Mutakhir. Kata klarifikasi yang memiliki makna kabur dalam bentuk tanggung jawab akan memberikan celah kepada BPN untuk menyalahgunakan wewenangnya terkait kerugian yang timbul akibat adanya dokumen elektronik yang hasilnya tidak sesuai dengan kenyataan di lapangan, sehingga untuk mengetahui tanggung jawab dari BPN mengenai ketidaksesuain hasil pengecekan sertifikat secara elektronik maka penulis tertarik melakukan penulisan dengan judul "Tanggung Jawab Hukum Badan Pertanahan Nasional terkait Hasil Pengecekan Sertifikat secara Elektronik", dengan rumusan masalah sebagai berupa Bagaimana Pengaturan Pengecekan Sertifikat secara elektronik pada Permen Agraria 5/2017? Dan Bagaimana Tanggung Jawab Hukum BPN terkait ketidaksesuaian hasil pengecekan sertifikat secara elektroknik? Tujuan dalam penulisan artikel ini yaitu untuk mengetahui pengaturan pengecekan sertifikat secara elektronik dan mengkaji tanggung jawab BPN terkait ketidaksesuaian hasil pengecekan sertifikat hak atas tanah dalam Permen Agraria 5/2017.

State of art dari penulisan ini mengambil dari contoh penulisan artikel yang dijadikan sebagai panduan untuk penulisan jurnal ini. Adapun contoh yang diambil berupa artikel yang berkaitan dengan pengecekan sertifikat hak atas tanah. Adapun artikel pertama tersebut berjudul "Efektivitas Pengecekan Sertifikat Terhadap Pencegahan Sengketa Tanah Dalam Proses Peralihan Hak Atas Tanah" yang ditulis oleh Chintya Agnisia Putri dan Gunarto dari Universitas Islam Sultan Agung pada tahun 2018. Rumusan masalah yang diangkat pada artikel tersebut mengenai prosedur pengecekan sertifikat dan mengenai efektifitas pengecekan sertifikat dalam kaitannya mencegah terjadinya sengketa tanah ketika proses peralihan hak atas tanah. Kesimpulan dari artikel tersebut yaitu prosedur pengecekan sertifikat dilakukan dengan menyerahkan sertifikat asli dan data pendukung ke BPN, dan mengenai keefektifitasannya pengecekan sertifikat hak atas tanah efektif untuk mencegah terjadinya sengketa di 
Kantor Pertanahan Kota Makassar dan wajib dilakukan pada saat peralihan hak atas tanah. 6

Selanjutnya artikel kedua berjudul "Pengaturan Pengecekan Sertipikat Hak Atas Tanah: Belum Mewujudkan Perlindungan Hak Asasi Manusia" yang ditulis oleh Lilik Warsito dari Universitas Darul Ulum Islamic Centre Sudirman pada tahun 2020. Rumusan masalah yang diangkat yaitu mengenai pengaturan pengecekan sertifikat hak atas tanah dan mengenai pengecekan sertifikat hak atas tanah ditinjau dari Hak Asasi Manusia. Kesimpulan dari artikel tersebut yaitu Ketentuan pengecekan sertipikat hak atas tanah diatur dalam Peraturan Menteri Negara Agraria/ Kepala Badan Pertanahan Nasional Nomor 3 Tahun 1997 Ketentuan Pelaksanaan Peraturan Pemerintah Nomor 24 Tahun 1997 Tentang Pendaftaran Tanah (selanjutnya disebut PMNA 3/1997) pada pasal 97 yang dalam ketentuan tersebut hanya PPAT yang dapat mengajukan pengecekan sertifikat, dan untuk memberikan kepastian hukum dan pengakuan hak asasi manusia, maka seharusnya tidak hanya PPAT yang dapat mengajukan pengecekan sertifikat namun juga dapat diajukan oleh pemilik sertifikat hak atas tanah. ${ }^{7}$

Artikel yang berkaitan dengan pengecekan sertifikat hak atas tanah masih sebatas mengenai pengecekan sertifikat hak atas tanah sebagaimana diatur dalam PP 24/1997 dan PMNA 3/1997 yang dimana dinamakan pengecekan sertifikat secara manual dan kedua artikel tersebut hanya sebatas mengkaji mengenai prosedur dan pengaturan pengecekan sertifikat secara manual, efektivitas pengecekan sertifikat hak atas tanah untuk mencegah terjadinya sengketa dan mengenai pengecekan sertifikat hak atas tanah ditinjau dari Hak Asasi Manusia. Sedangkan penelitian ini mengenai pengecekan sertifikat hak atas tanah secara elektronik yang ditekankan pada tanggung jawab BPN terkait adanya ketidaksesuaian hasil pengecekan hal ini dikarenakan adanya peraturan yang dikeluarkan oleh Menteri Agraria mengenai Layanan Informasi Pertanahan secara Elektronik yang mulai berlaku sejak tanggal 25 April 2017 yang didalamnya terdapat pemberlakuan pengecekan sertifikat hak atas tanah secara elektronik guna menggeser keberadaan pengecekan sertifikat hak atas tanah yang dilakukan secara manual.

\section{Metode Penelitian}

Artikel ilmiah ini menggunakan metode penelitian hukum normatif dengan mengkaji pengaturan pengecekan sertifikat secara elektronik dan bentuk tanggung jawab BPN terkait ketidaksesuaian hasil pengecekan sertifikat secara elektronik pada Permen Agraria 5/2017 mengenai pemberian tanggung jawab oleh BPN yang berupa klarifikasi. Jenis pendekatan yang digunakan dalam penelitian ini ialah Pendekatan Perundang-Undangan, dan Pendekatan Konseptual. Bahan hukum dalam artikel ilmiah ini terdiri dari bahan hukum primer, bahan hukum sekunder, dan bahan hukum tersier. Seluruh bahan hukum dikumpulkan dengan teknik studi dokumen, dan pula dilakukan analisis kajian dengan menggunakan analisis deskriptif kualitatif

${ }^{6}$ Putri, C. A., dan Gunarto, G., Op.cit, p. 273

7 Warsito, L. (2020). Pengaturan Pengecekan Sertipikat Hak Atas Tanah: Belum Mewujudkan

Perlindungan Hak Asasi Manusia. JPeHI: Jurnal Penelitian Hukum Indonesia, 1(1)., h. 14

e-ISSN:2746-4172, http:/ / www.ejournal.undaris.ac.id/index.php/ipehi/article/view/145/108. 
melalui prosedur penelitian yang menggunakan bahan deskriptif dengan menjelaskan, menguraikan, menggambarkan dan menjabarkan berdasarkan bahan hukum yang didapat. 8

\section{Hasil dan Pembahasan}

\subsection{Pengecekan Sertifikat Hak Atas Tanah \\ 3.1.1. Pengaturan Pengecekan Sertifikat secara Elektronik Pada Permen Agraria $5 / 2017$}

Pengecekan sertifikat hak atas tanah secara elektronik adalah suatu perkembangan dari revolusi industri 4.0 yang merupakan era baru berupa internet of things. Pelayanan pengecekan sertifikat hak atas tanah secara elektronik diatur pada Permen Agraria 5/2017 yang dibentuk untuk meningkatkan pelayanan informasi pertanahan dengan memberikan kemudahan, serta pelayanan yang cepat, dan biaya rendah serta mengikuti kebutuhan masyarakat. Pelayanan pengecekan sertifikat secara elektronik juga merupakan gerakan zero waste paper, yang dimana pengurangan tumpukan berkas pada kantor BPN, dan juga dengan penyimpanan berdasar pada database akan mempermudah pemberian layanan pada masyarakat.

Pengecekan sertifikat secara elektronik merupakan salah satu bagian dari proses pendaftaran tanah. 5 (lima) asas pendaftaran tanah merupakan asas yang wajib dilakukan dalam pelaksanaan pendaftaran tanah yaitu asas sederhana, aman, terjangkau, mutakhir dan terbuka..$^{9}$ Maka pengecekan sertifikat secara elektronik yang merupakan bagian dari proses pendaftaran tanah wajib dilaksanakan dengan mengikuti asas-asas pendaftaran tanah. Pengecekan sertifikat secara elektronik diundangkan pula dengan tujuan memberikan kemudahan bagi masyarakat untuk mengecek sertifikat hak atas tanahnya secara elektronik sehingga dapat dijangkau diseluruh wilayah Indonesia tanpa harus mendatangi BPN, hal ini telah memenuhi unsur sederhana, terjangkau dan terbuka. Kemudian dengan pengecekan sertifikat secara elektronik maka BPN wajib selalu memperbaharui sistem pangkalan datanya, sehingga berkesinambungan dengan data yang terdapat di lapangan, hal ini telah memenuhi asas mutakhir. Proses pengecekan sertifikat secara elektronik yang mewajibkan BPN dalam melaksanakan kegiatan yang berdasarkan asas mutakhir, akan memberikan rasa aman kepada masyarakat, yang dalam hal ini memenuhi asas aman.

Layanan pengecekan tanah diatur pada Pasal 1 angka 5 Permen Agraria 5/2017 adalah layanan yang dipergunakan untuk pemeriksaan kesesuaian data fisik dan data yuridis yang tercantum dalam sertifikat hak atas tanah dengan data elektronik yang terdapat pada pangkalan data BPN. Pelayanan penyajian data pertanahan oleh BPN yang dilakukan secara elektronik merupakan salah satu implementasi dari tujuan

8 Diantha, I.M.P., Dharmawan, N.K.S, I Gede Artha. (2018) Metode Penelitian Hukum dan Penulisan Disertasi, Denpasar:Swasta Nulus.h. 65.

${ }^{9}$ Hisbullah, R.W. (2018). Asas Publisitas pada Pelaksanaan Program Nasional Agraria dalam Rangka mewujudkan Efektivitas Pelayanan Publik. Madani Legal Review, 2(1), h.42, e-ISSN: 2580-6319, https://jurnal.umpar.ac.id/index.php/malrev/article/view/331/285. 
pendaftaran tanah, yakni setiap orang memiliki haknya untuk dapat mengetahui datadata tanah mereka yang telah terdaftar dan tersimpan pada pangkalan data BPN. ${ }^{10}$

Pengecekan Sertifikat secara elektronik dipertegas diatur pada Pasal 2 ayat (2) huruf a Permen Agraria 5/2017. Adapun yang dapat mengajukan permohonan untuk melakukan pengecekan sertifikat hak atas tanah diatur pada Pasal 3 Permen Agraria 5/2017 yaitu:

a. "Pemegang Hak atas Tanah/Kuasanya,

b. Pejabat Pembuat Akta Tanah

c. Notaris

d. Kantor Lelang Negara

e. Kantor Jasa Surveyor Kadaster Berlisensi,

f. Pihak Bank, dan

g. pihak lain yang ditetapkan oleh Menteri."

Pengecekan sertifikat elektronik wajib dilakukan oleh PPAT sebelum membuat akta otentik dimana didalamnya berupa perbuatan hukum pada sertifikat hak atas tanah, yang dimana diatur dalam ketentuan Pasal 4 Permen Agraria 5/2017. Adapun proses pengecekan sertifikat hak atas tanah secara elektronik yang dilakukan melalui aplikasi Layanan Informasi Pertanahan yang dibuat oleh BPN berdasarkan pasal 2 Permen Agraria 5/2017. Kemudian hasil dari pengecekan sertifikat hak atas tanah secara elektronik berupa dokumen elektronik yang dapat dicetak mandiri oleh pemohon setelah melakukan pembayaran PNBP senilai Rp. 50.000,00 (lima puluh ribu rupiah), selambat-lambatnya diberikan batas waktu 3 (tiga) hari setelah tanggal pendaftaran permohonan pengecekan sertfikat pada sistem aplikasi layanan elektronik. Hasil pengecekan sertifikat hak atas tanah secara elektronik hanya berlaku 7 (tujuh) hari, pengaturan tersebut terdapat dalam Pasal 10 ayat (2) Permen Agraria 5/2017.

\subsubsection{Perbandingan Pengecekan Sertifikat Hak atas Tanah secara Manual dan Pengecekan Sertifikat Hak atas Tanah secara Elektronik}

PP 24/1997 merupakan peraturan pemerintah mengenai pendaftaran tanah yang berkaitan dengan UUPA pada pasal 19. PP 24/1997 memiliki ketentuan pelaksana, yaitu Peraturan Kepala Badan Pertanahan Nasional Nomor 8 Tahun 2012 tentang Perubahan atas Peraturan Menteri Negara Agraria/Kepala Badan Pertanahan Nasional Nomor 3 Tahun 1997 tentang Ketentuan Pelaksanaan Peraturan Pemerintah Nomor 24 Tahun 1997 tentang Pendaftaran Tanah (selanjutnya disebut Perkaban No. 8/2012).

Pada Perkaban No. 8/2012 mengenai pengecekan sertifikat tercantum dalam pasal 97 yang mengatur bahwa, sebelum PPAT melakukan pembuatan akta tanah baik berupa pemindahan, ataupun halnya pembebanan hak atas tanah maka PPAT harus memeriksa sertifikat kepemilikan tanah terlebih dahulu, mencocokkannya dengan data di buku tanah yang terdapat di BPN setempat, dengan menunjukkan sertifikat hak atas tanah asli tersebut kepada petugas BPN untuk dilakukan penyesuaian. Mengenai istilah "pengecekan sertifikat" dapat dilihat bahwa tidak adanya kata pengecekan itu

${ }^{10}$ Erwiningsih, Winahyu \& Sailan, F.Z. (2019). Hukum Agraria Dasar-Dasar dan Penerapannya di Bidang Pertanahan.Yogyakarta: UII Press. h. 188 
sendiri pada ketentuan pelaksana pendaftaran tanah, tetapi pengecekan tersebut dikenal dengan istilah "pemeriksaan kesesuaian data". ${ }^{11}$

Pengalihan hak atas tanah yang sebelumnya wajib melakukan pendaftaran tanah, maka terjadilah pemeliharaan data yang salah satunya berupa pengecekan sertifikat dimana pemeliharaan data pendaftaran tanah diatur dalam ketentuan pasal 1 ayat (12) PP 24/1997 yang memiliki arti bahwa suatu pada suatu proses kegiatan pendaftaran tanah yang digunakan demi menyesuaikan data-data pertanahan baik fisik maupun yuridis terdapat di BPN yang walaupun nanti akan terjadi perubahan dikemudian hari. Ketentuan Pasal 34 ayat (1) PP 24/1997 mengatur bahwa, setiap orang yang mempunyai kepentingan pada sertifikat hak atas tanah tersebut mempunyai hak untuk memahami dan mengetahui apa yang ada di dalam data fisik maupun yuridis yang tercatat dan tersimpan di BPN, baik untuk mengetahui mengenai peta pendaftarannya, daftar tanah, serta surat ukur/gambar situasi dan buku tanah yang berhubungan dengan kepentingannya.

Terdapat perbedaan signifikan terjadi pada proses dan hasil pengecekan tanah yang dulu secara manual, proses pengecekan wajib datang ke kantor BPN dan kemudian hasil dari Pengecekan Sertifikat Hak atas tanah berupa stempel berisikan bahwa sertifikat tersebut bersih dari sitaan, tanggungan ataupun pemblokiran. Hal ini diatur dalam pasal 97 ayat (3) Perkaban No. 8/2012, hasil dari pengecekan sertifikat dibubuhkan cap oleh Kepala Kantor BPN atau Pejabat yang ditunjuk dengan kalimat "Telah diperiksa dan sesuai dengan daftar di Kantor Pertanahan", dan diberikan paraf dan tanggal pengecekan. Kemudian hasil dari pengecekan sertifikat hak atas tanah secara manual memiliki jangka waktu hingga 3 bulan, ini berarti apabila selama 3 bulan tidak terdapat perbuatan hukum, maka sertifikat hak atas tanah tersebut wajib dilakukan pengecekan kembali.

Hal ini berbeda pada Pengecekan Sertifikat Hak atas Tanah yang dilakukan melalui Aplikasi Layanan Informasi Pertanahan secara elektronik, dimana proses pengecekan dilakukan oleh pihak PPAT di kantornya sendiri dengan menggunakan akun yang telah dibuat tanpa harus mendatangi Kantor BPN. Hasil dari pengecekan secara elektronik berbeda dengan pengecekan secara manual. Hasil dari pengecekan secara elektronik masuk dalam kategori Dokumen Elektronik yang diatur berdasarkan Pasal 1 angka 2 Permen Agraria 5/2017. Perbedaan pula telihat dari dokumen elektronik di cetak sendiri oleh PPAT setelah PPAT melakukan permohonan dan pembayaran PNBP, hasil tersebut bukan berupa cap dan tulisan "Telah diperiksa dan sesuai dengan daftar di Kantor Pertanahan".

Pengecekan sertifikat hak atas tanah sebagaimana ketentuan Perkaban No. 8/2012 yang tidak sesuai dengan data yang tedaftar di BPN, maka sesuai dengan Pasal 97 ayat (5) huruf b akan dikeluarkan Surat Keterangan Pendaftaran Tanah ( selanjutnya disebut SKPT). SKPT ini akan menerangkan hasil berupa catatan-catatan apabila sertifikat sedang terjadi sengeketa sehingga dilakukan sita jaminan, atau sertifikat terdapat pemasangan hak tanggungan serta sertifikat terdapat pemblokiran baik itu blokir

11 Silvia dan Diana, 2016, Pengecekan Sertifikat dalam Pembuatan Akta Jual Beli Tanah untuk Mencegah Terjadinya Sengketa Pertanahan di Kota Pekanbaru. Thesis, Fakultas Hukum Universitas Andalas, Padang, hal. 5 
internal maupun eksternal dari pihak ketiga yang mengajukan blokir ke BPN. Apabila dikeluarkan SKPT pada pengecekan sertifikat secara manual, hasilnya tidak dapat digunakan oleh Notaris/PPAT yang akan melanjutkan proses pembuatan akta perbuatan hukum. Notaris/PPAT yang akan melakukan pembuatan akta perbuatan hukum hanya dapat menggunakan hasil pengecekan sertifikat bukan hasil SKPT. Sehingga dengan dikeluarkannya SKPT akibat dari asli sertifikat hak atas tanah menunjukkan adanya perbedaan dengan data yang terdapat pada BPN, maka pemohon harus menyelesaikan permasalahan yang terdapat pada hak atas tanahnya apabila ingin melanjutkan pada proses perbuatan hukum.

Berbeda dengan pengecekan sertifikat secara elektronik melalui Layanan Aplikasi Pengecekan Tanah, dimana pada pengecekan sertifikat secara elektronik tidak mengeluarkan SKPT apabila sudah diketahui adanya ketidaksamaan antara sertifikat dengan buku tanah yang terdapat di BPN, sehinga pada Layanan Aplikasi Pengecekan Tanah tetap mengeluarkan dokumen elektronik berupa Pengecekan Sertifikat, walaupun terdapat ketidaksamaan. Apabila kredibilitas pemegang hak atas tanah diragukan oleh pihak Notaris/PPAT maka Notaris/PPAT diwajibkan menolak untuk melakukan permohonan layanan informasi pertanahan secara elektronik, diatur pada Pasal 5 ayat (5) Permen Agraria 5/2017. Dengan ketentuan pada pasal tersebut dapat dijadikan dasar untuk pihak Notaris/PPAT menolak pengecekan sertifikat secara elektronik jika terdapat hal-hal yang disangkakan atau dirasa kredibilitas dari sertifikat hak atas tanah kurang.

\subsection{Tanggung Jawab Hukum BPN terkait Ketidaksesuaian Hasil Pengecekan Sertifikat secara Elektronik}

\subsubsection{Proses Pengecekan Sertifikat secara Elektronik Pada Permen Agraria 5/2017}

Pengecekan sertifikat secara elektronik dilakukan pada aplikasi Layanan Informasi Pertanahan yang telah dibuat oleh Kementerian. Pemilik hak atas tanah, PPAT dan Notaris dapat menjadi pemohon pengajuan pengecekan sertifikat secara elektronik sesuai dengan pada Pasal 3 Permen Agraria 5/2017.

Namun sebelum melakukan permohonan, diwajibkan kepada pemohon untuk melakukan pendaftaran diri pada aplikasi Layanan Informasi Pertanahan, dan dari pendaftaran tersebut diberikan identitas berupa username dan password yang akan digunakan seterusnya.

Pengajuan permohonan pengecekan sertifikat secara elektronik memerlukan beberapa lampiran yang wajib dipenuhi oleh pemohon, hal ini diatur dalam pasal 5 ayat (2) Permen Agraria 5/2017, yaitu berupa:

a. Identitas Pemegang Hak atas Tanah atau Kuasanya (yang berupa Kartu Tanda Penduduk serta Kartu Keluarga), apabila menggunakan kuasa maka disertakan dengan Surat Kuasa

b. Sertifikat asli dan/atau dapat diuraikan dalam surat permohonan yang isi surat permohonan sesuai dengan isi sertifikat asli

c. Surat Pernyataan Keaslian sertifikat, dan itikad baik serta bertanggung jawab atas penggunaan layanan

d. Surat penugasan dari instansi yang berwenang 
Persyaratan tersebut dilampirkan dalam bentuk dokumen elektronik, yang akan di unggah pada aplikasi Layanan Informasi Pertanahan. Kemudian setelah pemohon melengkapi lampiran sesuai dengan Pasal 5 Permen Agraria 5/2017, maka sistem akan mengeluarkan bukti pendaftaran sesuai Pasal 7 ayat (2) Permen Agraria 5/2017 yang mengatur bahwa,

"Bukti pendaftaran permohonan sebagaimana dimaksud pada ayat (1) paling sedikit memuat:

a. nomor berkas pendaftaran permohonan;

b. tanggal pendaftaran permohonan;

c. nama pemohon; dan

d. kode pembayaran biaya Layanan Informasi Pertanahan secara Elektronik."

Setelah mendapatkan bukti permohonan maka selanjutnya berdasarkan Pasal 9 Permen Agraria 5/2017, pemohon membayar melalui bank persepsi selambatlambatnya diberikan waktu 3 (tiga) hari setelah tanggal pendaftaran permohonan. Apabila pemohon melebihi jangka waktu 3 (tiga) hari dan pemohon gagal melakukan pembayaran, pemohon wajib mengajukan kembali permohonan. Pemohon yang telah melakukan pembayaran, permohonan akan diproses oleh sistem BPN. Hasil pengecekan sertifikat hak atas tanah akan muncul pada aplikasi Layanan Informasi Pertanahan, dan dapat dicetak secara mandiri oleh pemohon. Hasil pengecekan sertifikat hanya berlaku 7 (tujuh) hari kalender, diatur berdasarkan Pasal 10 ayat (2) Permen Agraria 5/2017. Hal ini memiliki arti bahwa, apabila dalam 7 (tujuh) hari tidak dilakukan perbuatan hukum pada sertifikat hak atas tanah, maka wajib melakukan permohonan pengecekan sertifikat kembali dengan proses yang sama.

\subsubsection{Tanggung Jawab Hukum BPN terkait Ketidaksesuaian Hasil Pengecekan Sertifikat secara Elektronik Pada Permen Agraria 5/2017}

Ketidaksesuaian hasil pengecekan sertifikat secara elektronik menimbulkan kerugian pada PPAT dan masyarakat, yang dalam hal ini terdapat kerugian materiil dan kerugian immateriil. Adapun kerugian materiil adalah kerugian yang dapat dihitung dan dinominalkan, sedangkan kerugian immaterill adalah kerugian yang timbul atas hilangnya suatu kesempatan yang memungkinkan terjadi dikemudian hari. ${ }^{12}$ Kerugian pada masyarakat yang akan melakukan perbuatan hukum berupa jual-beli akan menimbulkan kerugian materiil dan immateriil. Kerugian materiil yaitu berupa biayabiaya yang keluar seperti pembayaran PNBP pada pengecekan sertifikat yang hasil pengecekan tidak sesuai dengan sertifikat aslinya. Hasil pengecekan yang tidak sesuai tersebut tidak dapat dipergunakan sebagai dasar bagi PPAT untuk melanjutkan ke proses pembuatan akta jual beli. Hal ini merugikan masyarakat karena harus mengeluarkan biaya lagi untuk melakukan pengecekan sertifikat kembali, dimana harus membayar PNBP terlebih dahulu sebelum hasil pengecekan keluar. Masyarakat khususnya penjual yang memerlukan dana cepat dengan menjual tanah pula akan mengalami kerugian immateriil berupa timbulnya rasa tidak percaya dari pembeli kepada penjual terkait kepemilikan tanah tersebut, sehingga hal ini bertalian dengan

${ }_{12}$ Heriyana, I. M., Dewi, A.A.S., \& Ujianti, N.M.P. (2020). Gugatan Ganti Kerugian dalam Kasus Pencemaran Nama Baik menurut Kitab Undang-Undang Hukum Perdata. Jurnal Preferensi Hukum, 1(1), h.87, doi https:// doi.org/10.22225/iph.1.1.1989. 
kerugian materiil penjual yang harus mengeluarkan tenaga dan biaya tambahan untuk mendapatkan hasil pengecekan sertifikat secara elektronik yang sesuai dengan aslinya agar proses jual beli dapat dilaksanakan. Kemudian kerugian pula timbul pada pembeli yang memerlukan tempat tinggal menjadi terhambat dan menjalani proses yang cukup lama diakibatkan karena tidak bisa dilakukan pembuatan akta jual beli di PPAT. PPAT pula harus mengeluarkan tenaga dan biaya untuk meminta tanggung jawab dari BPN terkait kesalahan diakibatkan tidak diperbaharuinya sistem pangkalan data, seperti halnya PPAT perlu mendatangi kantor BPN memerlukan biaya bensin, tenaga dan waktu, tentu hal ini tidak akan terjadi apabila BPN selalu memperbaharui pangkalan datanya.

Menurut Kamus Besar Bahasa Indonesia (selanjutnya disebut KBBI), kata tanggung jawab memuat arti suatu keadaan yang mewajibkan seseorang atau lebih untuk menanggung segala sesuatunya apabila terjadi sesuatu orang tersebut dapat untuk dituntut, kemudian dapat dipersalahkan, diperkarakan, dan sebagainya. ${ }^{13}$ Maka dengan arti tersebut tanggung jawab tidak dapat berdiri sendiri dikarenakan suatu akibat dari adanya hak dan kewajiban seseorang sebagai subjek hukum yang tidak terpenuhi sehingga dari keadaan tersebut terdapat pihak yang wajib menanggung akibatnya. Dapat ditafsirkan bahwa tanggung jawab harus memiliki dasar dari munculnya hak dari seseorang untuk menuntut sekaligus memberi kewajiban bagi orang lain untuk bertanggung jawab atas perbuatannya. ${ }^{14} \mathrm{BPN}$ dan/atau pejabat yang ditunjuk memiliki kaitan yang erat dengan kewajiban, hak dan tanggung jawab. Teori yang berkaitan dengan tanggung jawab pejabat terdapat 2 (dua) teori dari Kranenburg dan Vetig, yaitu: 15

a. Teori Fautes Personalle, yang memiliki arti apabila terdapat kerugian pada pihak ketiga, maka yang bertanggung jawab adalah pejabat berwenang yang dibebankan atas perbuatannya yang telah menimbulkan kerugian tersebut.

b. Teori Fautes de Services, yang memiliki arti lebih menekankan bahwa pertanggung jawaban hanya dibebankan pada jabatannya.

Berdasarkan Teori Fautes de Services diatas, maka BPN bertanggung jawab atas ketidaksesuaian hasil pengecekan sertfikat secara elektronik. Kerugian terhadap PPAT dan masyarakat berupa materiil maupun imateriil atas ketidaksesuaian hasil pengecekan sertifikat secara elektronik dibebankan kepada pada instansi dari pejabat yang bersangkutan, dalam hal ini pembebanan kepada jabatan Kepala BPN mewakili instansi yang karena kesalahannya tidak memperbaharui pangkalan data. Pada teori ini beban tanggung jawab ditujukan kepada jabatan Kepala Kantor BPN selaku perwakilan dari instansi pertanahan.

\footnotetext{
${ }^{13}$ Kamus Besar Bahasa Indonesia (2021). https://kbbi.web.id/tanggung\% 20jawab , (diakses pada hari Rabu , 07 April 2021)

${ }^{14}$ Anggraeni, S. Z., \& Marwanto, M. Kewenangan dan Tanggung Jawab Hukum Pejabat Pembuat Akta Tanah Dalam Pelaksanaan Pendaftaran Hak Tanggungan Secara Elektronik. Acta Comitas: Jurnal Hukum Kenotariatan,5(2), h. 268, doi https://doi.org/10.24843/AC.2020.v05.i02.p05.

15 Rismayanthi, I. A. W. (2016) Tanggung Jawab Pejabat Pembuat Akta Tanah ( PPAT) Terhadap Pendaftaran Peralihan Hak Atas Tanah Yang Menjadi Objek Sengketa. Acta Comitas: Jurnal Hukum Kenotariatan, 1(1), h. 77-93, doi https://doi.org/10.24843/AC.2016.v01.i01.p07.
} 
BPN bertanggung jawab atas kerugian yang timbul hal ini pula dikarenakan BPN memiliki kewenangan dalam pelayanan dan melaksanakan tugas pemerintahan dibidang pertanahan berdasarkan Pasal 1 ayat (22) PP 24/1997. Kewenangan BPN tersebut merupakan kewenangan atribusi yang artinya kewenangan yang diperoleh dan bersifat asli dikarenakan berasal dari ketentuan perundang-undangan. ${ }^{16}$ Sehingga dalam hal ini BPN memiliki tanggung jawab dari kewenanganya dalam penyelenggaraan pengecekan sertifikat secara elektronik sebagai salah satu proses pendaftaran tanah.

Penyelenggaraan kewenangan BPN pada proses pendaftaran tanah dalam pengecekan sertifikat secara elektronik terdapat kesalahan pada hasil pengecekan sertifikat hak atas tanah. Kesalahan tersebut dapat berupa kesalahan pada data-data fisik maupun yuridis, baik itu seperti kesalahan tulis nama, tanggal lahir, nomor surat ukur ataupun gambar situasi. Kesalahan juga dapat terjadi pada pengeluaran dokumen elektronik pengecekan sertifikat walaupun terjadi sita jaminan ataupun pemblokiran pada sertifikat hak atas tanah tersebut. Padahal dalam Perkaban No.8/2012 Pasal 97 ayat (5) huruf $\mathrm{b}$ akan dikeluarkan SKPT apabila terjadi perbedaan sertifikat hak atas tanah dengan buku tanah di BPN, dengan dikeluarkannya SKPT akan memberikan rasa kehati-hatian dan waspada pada pihak pemohon apabila ingin melakukan perbuatan hukum seperti jual-beli. Namun berbeda pada Pengecekan sertifikat secara elektronik, yang dimana walaupun terdapat kesalahan ataupun adanya sita jaminan, pemblokiran sekalipun tetap dikeluarkan dokumen elektronik pengecekan sertifikat. Hal ini akan berdampak pada Notaris/PPAT yang terbiasa dulunya melakukan pengecekan sertifikat hak atas tanah secara manual, yang dimana apabila hasil pengecekan tersebut sesuai maka sertifikat dapat dibubuhi cap dan stempel, sehingga menimbulkan pemikiran bahwa sertifikat hak atas tanah yang telah dilakukan pengecekan dan berhasil keluar hasilnya adalah sertifikat yang bersih dari sita jaminan dan pemblokiran. Hal tersebut tidak berlaku pada pengecekan sertifikat secara elektronik yang menggantikan pengecekan sertifikat secara manual, dikarenakan Notaris/PPAT harus teliti dalam membaca dokumen elektronik pengecekan sertifikat.

Kesalahan-kesalahan yang terjadi hasil pengecekan sertifikat hak atas tanah secara elektronik merupakan tanggung jawab dari pihak BPN, hal ini diatur secara tegas pada Pasal 10 ayat (4) Permen Agraria 5/2017. Hal ini dikarenakan BPN sebagai pihak yang berwenang dalam proses pendaftaran tanah dan pemeliharaan data pendaftaran tanah, wajib menerapkan asas aman dan mutakhir sesuai dengan yang tertuang dalam konsideran menimbang pada Permen Agraria 5/2017. Adapun asas mutakhir merupakan asas yang mewajibkan BPN sebagai penyelenggaran pendaftaran tanah harus selalu berkesinambungan dan sesuai dengan keadaan dilapangan. Hal ini berikaitan dengan asas aman yang merupakan pendaftaran tanah harus dilakukan dengan sebuah ketelitian dan kecermatan sehingga hasil dari pendaftaran tanah dan pemeliharaan data pendaftaran tanah tersebut akan memberikan jaminan kepastian secara hukum dan rasa aman pada masyarakat. ${ }^{17}$

BPN sebagai pihak penyelenggara pendaftaran tanah menjamin kebenaran data pertanahan baik itu fisik maupun yuridis pada sertifikat hak atas tanah tersebut, dan

16 Ridwan HR. (2013). Hukum Administrasi Negara. Jakarta: Raja Grafindo Persada. h. 105

${ }^{17}$ Erwiningsih, Winahyu \& Sailan, F.Z, Op.cit, h. 182 
memberikan kepastian hukum dengan menerapkan asas mutakhir, sehingga masyarakat akan merasa aman dikarenakan masyarakat memberikan kepercayaannya kepada BPN sebagai pemerintah yang memberikan jaminan kepastian dari hak atas tanah. Sehingga dapat terlihat bahwa pertanggung-jawaban dalam ketidaksesuaian hasil pengecekan sertifikat secara elektronik dikarenakan tidak memperbaharui sistem pangkalan data menganut prinsip pertanggung-jawaban berdasarkan kesalahan, maka dari itu BPN wajib bertanggung jawab apabila terjadi kesalahan dalam hasil pengecekan sertifikat hak atas tanah yang terdapat ketidaksesuaian dengan sertifikat aslinya (seperti kesalahan nama, tanggal lahir ataupun nomor surat ukur dan gambar situasi).

Lebih lanjut mengenai tanggung jawab pihak BPN berdasarkan pasal 10 ayat (5) Permen Agraria 5/2017, mengatur bahwa apabila terdapat ketidaksesuaian pada hasil pengecekan sertifikat secara elektronik maka dengan ini meminta klarifikasi kepada BPN yang mengeluarkan hasil pengecekan baik secara elektronik ataupun dengan menghubungi langsung ke kantor BPN setempat dengan membawa bukti hasil pengecekan sertifikat elektronik. Dapat ditafsirkan pada Pasal 10 ayat (5) Permen Agraria 5/2017 bahwa bentuk tanggung jawab yang diberikan oleh Pihak BPN adalah berupa klarifikasi. Menurut KBBI, kata klarifikasi memuat arti suatu penjelasan, menguraikan maupun pengembalian kepada suatu waktu yang telah terjadi dengan apa yang sebenarnya. ${ }^{18}$ Sehingga bentuk tanggung jaw ab hukum dari pihak BPN pada Permen Agraria 5/2017 berupa klarifikasi dengan memperbaiki sistem pangkalan data sehingga akan memberikan penjelasan dan pengembalian yang sesuai dengan sertifikat aslinya. Terkait dengan hasil pengecekan sertifikat hak atas tanah yang sudah terlanjur dicetak namun terdapat ketidaksesuaian, maka pemohon dapat mengulang untuk melakukan pengecekan sertifikat secara elektronik dengan proses yang sama.

\section{Kesimpulan}

Sesuai pembahasan diatas dapat ditarik kesimpulan yaitu, pengaturan pengecekan sertifikat secara elektronik terdapat pada Pasal 2 ayat (2) huruf a Permen Agraria 5/2017, yang dimana pengecekan sertifikat secara elektronik akan menggantikan pengecekan sertifikat secara manual yang diatur pada Perkaban No. 8/2012 dengan hasil berupa dokumen elektronik. Mengenai tanggung jawab hukum terkait adanya kesalahan pada hasil pengecekan sertifikat secara elektronik merupakan tanggung jawab dari pihak BPN sesuai dengan Pasal 10 ayat (4) dan ayat (5) Permen Agraria 5/2017 dengan tanggung jawab hukum berupa klarifikasi penjelasan dan perbaikan pada sistem pangkalan data. Sehubungan dengan kesimpulan tersebut, maka dapat direkomendasikan kepada pihak BPN untuk selalu memperbaharui secara berkesimbanungan sistem pangkalan datanya sehingga akan memberikan rasa aman pasa masyarakat, dan disarankan pada pihak Notaris/PPAT untuk selalu teliti dalam membaca hasil pengecekan sertifikat hak atas tanah secara elektronik, dikarenakan apabila sertifikat terdapat sita jaminan atau pemblokiran maka hasil pengecekan sertifikat secara elektronik tetap dikeluarkan.

\footnotetext{
${ }^{18}$ Kamus Besar Bahasa Indonesia (2021). https://kbbi.web.id/klarifikasi. (diakses pada hari Rabu, 07 April 2021)
} 


\section{Daftar Pustaka / Daftar Referensi}

\section{Buku:}

Arba, H.M. (2018). Hukum Agraria Indonesia. Jakarta: Sinar Grafika

Diantha, I.M.P., Dharmawan, N.K.S, I Gede Artha. (2018) Metode Penelitian Hukum dan Penulisan Disertasi, Denpasar:Swasta Nulus

Erwiningsih, Winahyu \& Sailan, F.Z. (2019). Hukum Agraria Dasar-Dasar dan Penerapannya di Bidang Pertanahan.Yogyakarta: UII Press

Ridwan HR. (2013). Hukum Administrasi Negara. Jakarta: Raja Grafindo Persada

\section{Jurnal:}

Anggraeni, S. Z., \& Marwanto, M. Kewenangan dan Tanggung Jawab Hukum Pejabat Pembuat Akta Tanah Dalam Pelaksanaan Pendaftaran Hak Tanggungan Secara Elektronik. Acta Comitas: Jurnal Hukum Kenotariatan, 5(2), doi https://doi.org/10.24843/AC.2020.v05.i02.p05

Heriyana, I. M., Dewi, A.A.S., \& Ujianti, N.M.P. (2020). Gugatan Ganti Kerugian dalam Kasus Pencemaran Nama Baik menurut Kitab Undang-Undang Hukum Perdata. Jurnal Preferensi Hukum, 1(1), doi https://doi.org/10.22225/jph.1.1.1989

Hisbullah, R. W. (2018). Asas Publisitas pada Pelaksanaan Program Nasional Agraria dalam Rangka mewujudkan Efektivitas Pelayanan Publik. Madani Legal Review, 2(1), e-ISSN: 2580-6319, https://jurnal.umpar.ac.id/index.php/malrev/article/view/331/285

Putri, C. A., dan Gunarto, G. (2018). Efektivitas Pengecekan Sertifikat Terhadap Pencegahan Sengketa Tanah Dalam Proses Peralihan Hak Atas Tanah. Jurnal Akta, 5(1), doi http://dx.doi.org/10.30659/akta.v5i1.2611

Rismayanthi, I. A. W. (2016) Tanggung Jawab Pejabat Pembuat Akta Tanah (PPAT) Terhadap Pendaftaran Peralihan Hak Atas Tanah Yang Menjadi Objek Sengketa. Acta Comitas: Jurnal Hukum Kenotariatan, 1(1), doi https://doi.org/10.24843/AC.2016.v01.i01.p07

Setiaw an, D. A. (2018). Keabsahan Surat Kuasa Membebankan Hak Tanggungan dalam Proses Peralihan Kredit Antar Bank. Jurnal Hukum dan Kenotariatan, 2(2), e-ISSN: 2655-7789, http://riset.unisma.ac.id/index.php/hukeno/article/download/1500/1473

Widiasih, N. K. A. E. A Kewenangan Notaris dalam Mensertifikasi Transaksi yang Dilakukan Secara Elektronik (Cyber Notary). Acta Comitas: Jurnal Hukum Kenotariatan, 5(1), doi https://doi.org/10.24843/AC.2020.v05.i01.p13

Warsito, L. (2020). Pengaturan Pengecekan Sertipikat Hak Atas Tanah: Belum Mewujudkan Perlindungan Hak Asasi Manusia. JPeHI: Jurnal Penelitian Hukum Indonesia, 1(1), $\quad$ e $\quad-\quad$ ISSN $\quad: \quad 2746-4172$, http://www.ejournal.undaris.ac.id/index.php/ipehi/article/view/145/108

Yamin, M., dan Zaidar, Z. (2018). Pendaftaran Tanah dalam Mewujudkan Kepastian Hukum atas Kepemilikan Tanah dan Upaya Meminimalisir Konflik 
Pertanahan. Jurnal Hukum Samudra Keadilan, 13(2), doi https://doi.org/10.33059/jhsk.v13i2.911

\section{Tesis:}

Silvia, Diana. (2016). Pengecekan Sertifikat dalam Pembuatan Akta Jual Beli Tanah untuk Mencegah Terjadinya Sengketa Pertanahan di Kota Pekanbaru. Fakultas Hukum Universitas Andalas

\section{Internet:}

Kamus Besar Bahasa Indonesia. (2021). https://kbbi.web.id/klarifikasi , (diakses pada hari Jumat, 01 Januari 2021)

Kamus Besar Bahasa Indonesia (2021). https://kbbi.web.id/tanggung\%20jawab , (diakses pada hari Rabu, 07 April 2021)

\section{Peraturan Perundang-undangan:}

Undang-Undang Nomor 5 tahun 1960 tentang Peraturan Dasar Pokok-Pokok Agraria (Lembaran Negara Republik Indonesia Nomor 104 tahun 1960, Tambahan Lembaran Negara Republik Indonesia Nomor 2043)

Peraturan Pemerintah Republik Indonesia Nomor 24 tahun 1997 tentang Pendaftaran Tanah (Lembaran Negara Republik Indonesia Nomor 59 Tahun 1997, Tambahan Lembaran Negara Republik Indonesia Nomor 3696)

Peraturan Menteri Agraria dan Tata Ruang/ Kepala BPN Republik Indonesia Nomor 5 Tahun 2017 Tentang Layanan Informasi Pertanahan Secara Elektronik (Berita Negara Republik Indonesia Tahun 2017 Nomor 612)

Peraturan Kepala Badan Pertanahan Nasional Nomor 8 Tahun 2012 tentang Perubahan atas Peraturan Menteri Negara Agraria/Kepala Badan Pertanahan Nasional Nomor 3 Tahun 1997 tentang Ketentuan Pelaksanaan Peraturan Pemerintah Nomor 24 Tahun 1997 tentang Pendaftaran Tanah 